\title{
アイスハーバー型魚道の流れの解析と 低流量・河床低下時の機能改善
}

\section{NUMERICAL ANALYSIS OF ICE HARVOR TYPE FISHWAY AND MODIFICATION OF ITS FUNCTION UNDER LOW DISCHARGE AND BED DEGRADATION CONDITION}

\author{
前野詩朗 $^{1} \cdot$ 吉田圭介 $^{2} \cdot$ 田中龍二 ${ }^{3}$ \\ Shiro MAENO, Keisuke YOSHIDA and Ryuji TANAKA

\begin{abstract}
2 正会員 博士（工）岡山大学准教授 環境生命科学研究科（下 700-8530 岡山市北区津島中 3-1-1)
\end{abstract} \\ 1 フェロー会員 博士（工）岡山大学教授 環境生命科学研究科（† 700-8530 岡山市北区津島中 3-1-1） \\ 3 学生会員 岡山大学環境理工学部環境デザイン工学科（†700-8530 岡山市北区津島中 3-1-1）
}

Ice harvor type fishway has commonly installed in Japan because it is a hybrid type fish ladder which is comprised of weir and orifice. But under severe low discharge and bed degradation condition, only the orifice flow state exists. In this case, fish cannot migrate through the fishways. To operate fishway in such severe flow condition, we proposed to close part of the orifices and put triangular shape blocks on the weir. Function of fishway was investigated by using 3D flow simulation. Numerically obtained flow state in the fishway with ten series of ice harbor type fishway shows in good agreement with the experimental results. And the proposed method can maintain favorable fishway function under low discharge and bed degradation condition.

Key Words: fishway, ice harbor, low discharge, bed degradation, 3D flow analysis

\section{1.はじめに}

河川を横断して設置される堰では, 魚類や甲殻類など の遡上降下を妨げることがないようにとの目的で近年 多くの魚道が設置されるようになった，例えば，魚が上 りやすい魚道事業などは，魚道の設置を後押ししてき た. 設置されている主な魚道の形式としては, デニール 型，バーチカルスロット型，プール型などであるが，プ 一ル型の改良である潜孔部の流れと越流が混在するア イスハーバー型の魚道が近年多く設置されている.この 魚道の特徵は非越流部の背面に静榣域が形成されてい つでも魚が休息できることである．しかし，写真-1に 示すように, 魚道下流側の河床低下により魚道の機能が 失われている箇所が見られる. また, 今後, 地球温暖化 により極端気象が起こることが予測されており，これま で以上の渇水や豪雨の頻発が危惧されている. 特にアイ スハーバー型の魚道では, 越流部を遡上する魚類も多く あるため, 渇水時のような流量が少ない場合や下流側の 河床が低下している場合には，潜孔部だけを流れる場合 も生じるため魚道が本来有している機能が失われてし まう。具体的には, 後出の図-6 の上側の写真に示すよ うに流量が少なく，下流の河床低下により下流端水位が 低下している場合には, 魚類は河床付近の潜孔部のみを

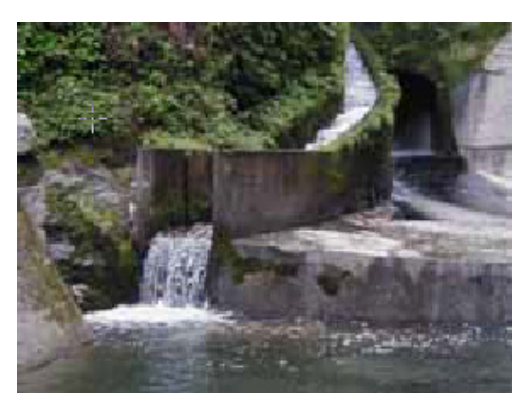

写真-1 河床低下による魚道機能の喪失状況 ${ }^{1)}$

使って遡上する必要があるため遊泳力の小さい魚類や 幼魚は遡上できなくなる可能性が高い.

以上のような背景を考慮して，本研究は，アイスハー バ一型の魚道を取り上げ, 渇水による流量の低下や魚道 下流側の河床低下が発生した場合においても極端な魚 道の機能低下を生じさせないような方策を数值解析に よる手法を用いて提案することを目的とする.

魚道内の流れを数值解析的に明らかにした研究とし ては，例えば著者ら ${ }^{2,3)}$ は，鉛直 2 次元モデルを対象と して VOF 法を用いてプールタイプの階段式魚道の数值 解析を行い, 魚道内の流れを再現できることを明らかに している。 また，浪平ら ${ }^{4}$ は，一般曲線座標系を用いて 越流部に丸みを持たせたプールタイプ魚道の流況解析 


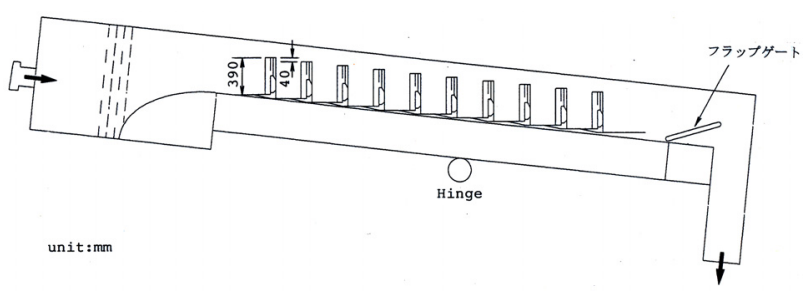

図-1 実験水路
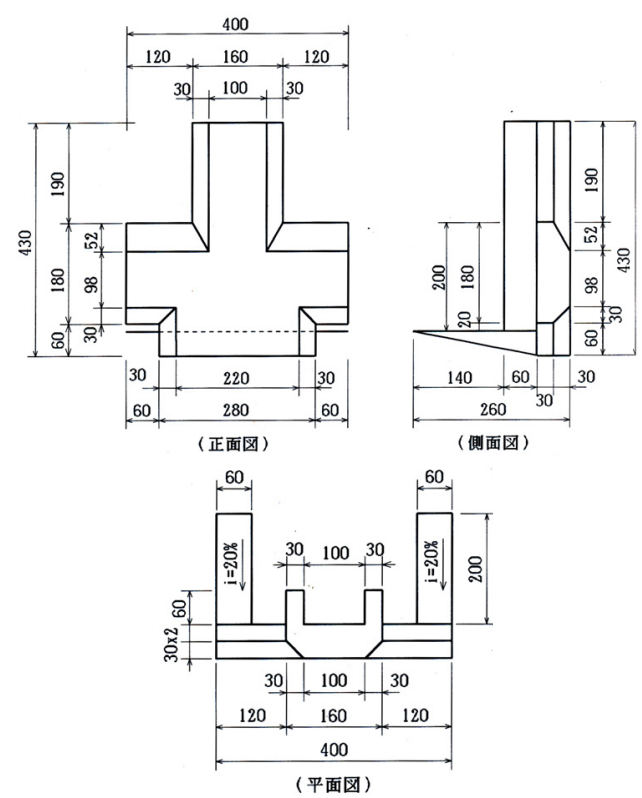

図-2 アイスハーバー型魚道詳細図，単位 $\mathrm{mm}$ )

表-1 解析条件

\begin{tabular}{|c|c|c|c|}
\hline 解析 & Case & 流量 $(1 / \mathrm{s})$ & 下流端水深 $(\mathrm{m})$ \\
\hline \multirow{4}{*}{ 検証 } & $1-1$ & 7.10 & 自由流出 $(0.03)$ \\
\cline { 2 - 4 } & $1-3$ & 7.10 & 0.241 \\
\cline { 2 - 4 } & $3-1$ & 12.92 & 自由流出 $(0.04)$ \\
\cline { 2 - 4 } & $3-3$ & 13.08 & 0.238 \\
\hline \multirow{4}{*}{ 改善 } & $1-1-\mathrm{O}$ & 7.10 & 自由流出 \\
\cline { 2 - 4 } & $1-2-\mathrm{O}$ & 7.10 & 0.12 \\
\cline { 2 - 4 } & $1-2-\mathrm{OW}$ & 7.10 & 0.12 \\
\cline { 2 - 4 } & $3-2-\mathrm{OW}$ & 13.0 & 0.12 \\
\hline
\end{tabular}

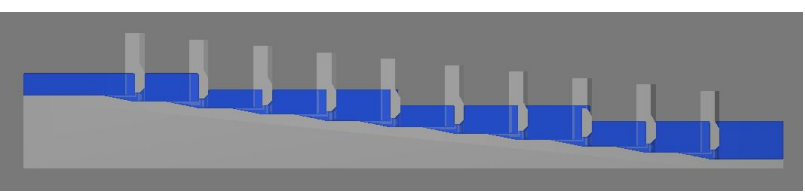

図-3 解析の初期水位条件

を行い解析の妥当性を示している．藤原ら を用いて, 越流部と潜孔部を有するアイスハーバー型魚 道の三次元流況シミュレーションを行い, 潜孔及び切り 欠きが存在する主流域の速い流れと, 水路中央付近の逆 流が再現できることを示した．後藤らのは，15 枚の薄肉 壁を有するデニール型魚道の流れを 3D-MPS 法を用い て解析し，平均流速分布を良好に再現できることを示し た. これらの数值魚道の構築に関する基礎的研究によ り, 魚道内の流れが数值解析的に得られるようになって きたが，プールタイプ魚道については，最大でも $5 つ$ 程 度のプール数を対象としたものである.

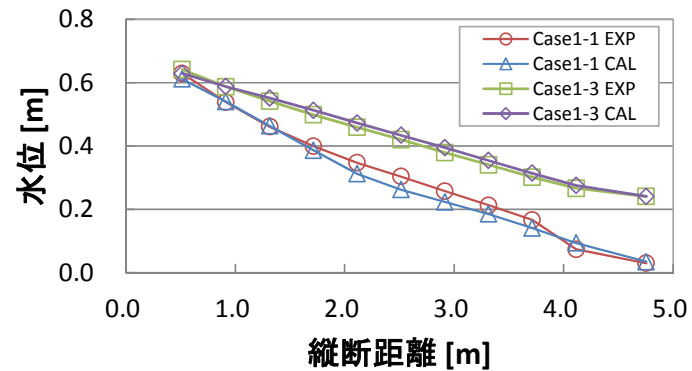

図-4 魚道流況の実験と解析の比較 (Case1-1)

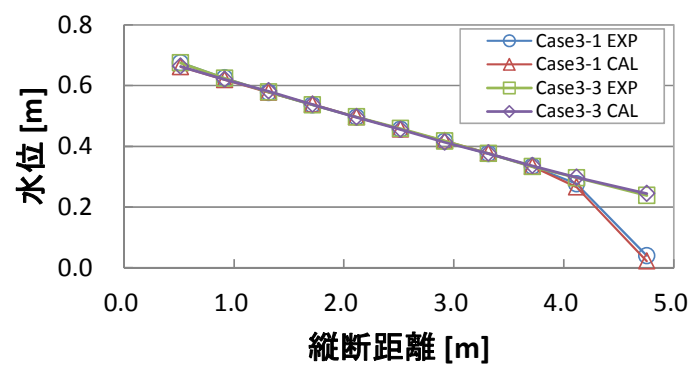

図-5 魚道流況の実験と解析の比較 (Case1-1)

本研究では，FLOW-3D（Flow Science Japan 社）を用 いた流況解析により，図-2 で示したアイスハーバー型 魚道を 10 段設置した流れの再現性を検討すると共に, 低流量, 河床低下時の魚道の機能維持のための方策を検 討する。

\section{2. 解析モデルの検証}

\section{（1）検証に用いた解析モデル}

解析に用いたFLOW-3Dは, 汎用3次元熱流体解析ソフ トウェアで，特に自由表面を高速・高精度に解くことに 優れている．本研究では，Kumarら`が図-1及び図-2に 示すアイスハーバー型魚道模型（太田川の西調子頭首工 に設置されている魚道を実物モデルとして実物に対す る縮尺1/5）を水路勾配1/10の水路に設置して実施した実 験結果を対象として解析の検証を行う. 図に示すアイス ハーバー型魚道は潜孔2箇所, 切り欠き 2 箇所の形式であ

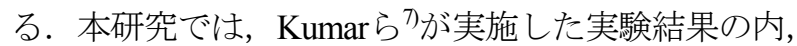
表-1の検証欄に示寸4ケースを取り上げて解析の妥当性 を検討する．ケース番号はKumarらの実験に合わせた．

Case1-1は，流量がかなり小さく，写真-1で示したよう に下流端の水位が低下して, 越流しなくなり魚道機能が 発揮されていない場合である.これは設計の際に想定さ れた小流量をフルードの相似則で模型に換算した流量 である7．Case1-3は，下流端水位を高くして魚道機能が 維持されている場合である. Case3-1, Case3-3は，流量が 多い場合について下流端条件をCase1 と同様に変えた場 合である．解析では，図-3に示す10段の魚道を含む領域 全体を $1 \mathrm{~cm}$ 格子のメッシュで分割して，初期条件として 図のように水を貯めた。乱流解析にはSmagorinskyモデ 


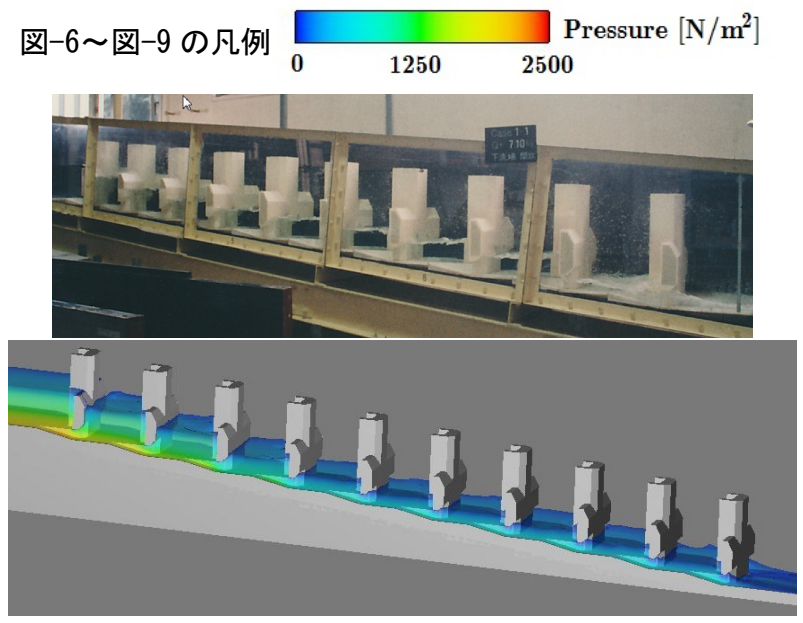

図-6 魚道流況の実験と解析の比較 (Case1-1)

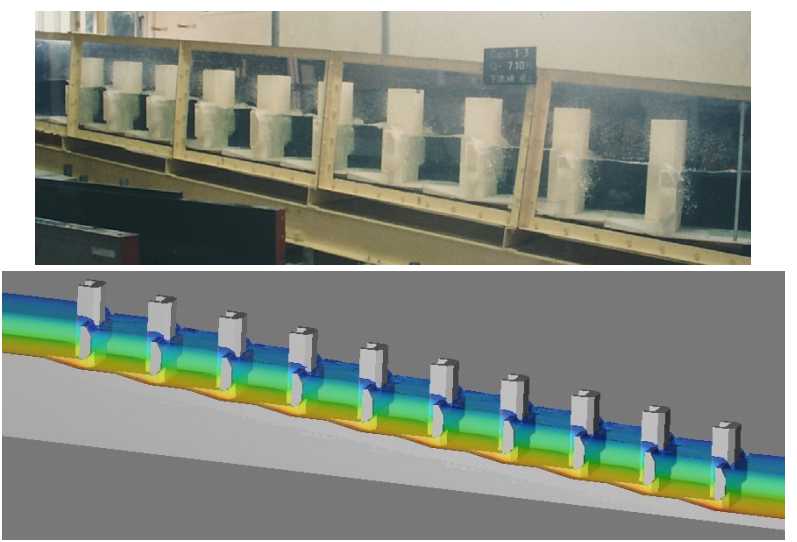

図-7 魚道流況の実験と解析の比較 (Case1-3)

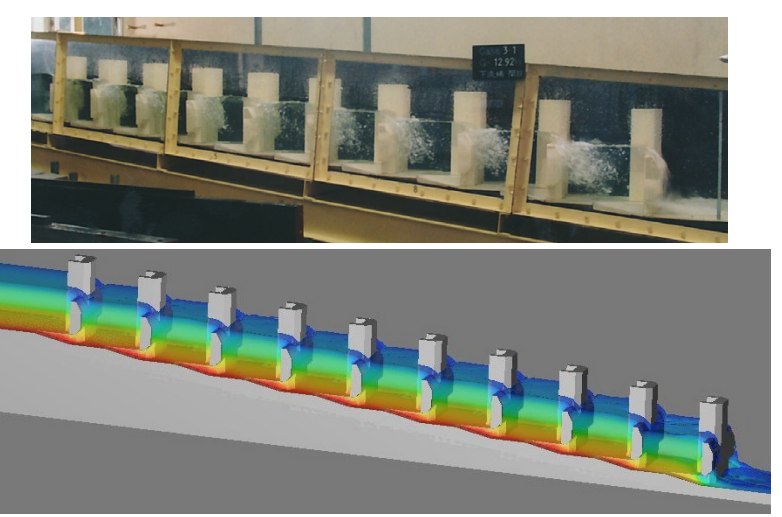

図-8＼cjkstart魚道流況の実験と解析の比較 (Case3-1)

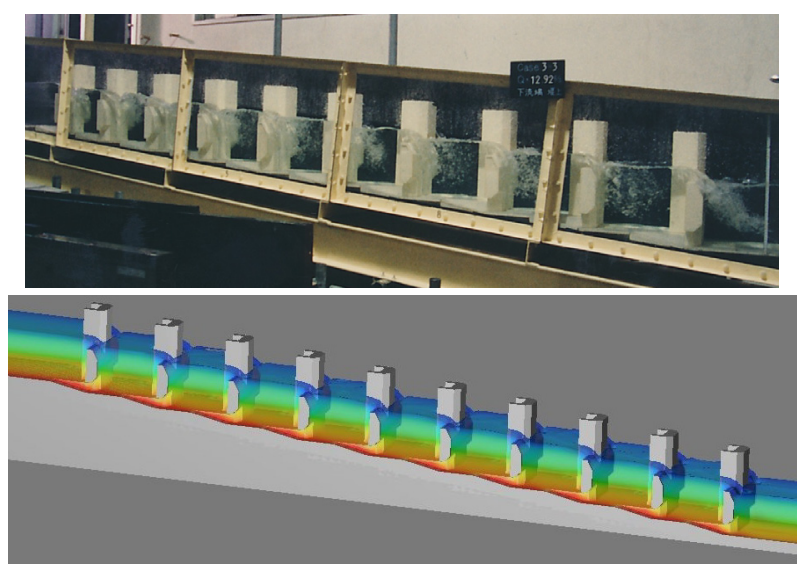

図-9 魚道流況の実験と解析の比較 (Case3-3)

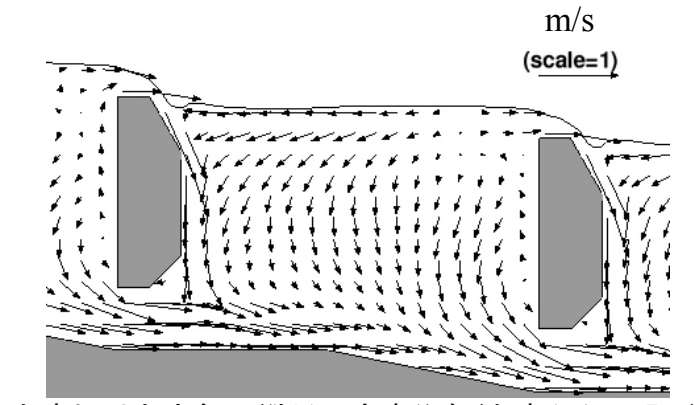

右岸切り欠き部の縦断面流速分布 (右岸から $3.5 \mathrm{~cm}$ )

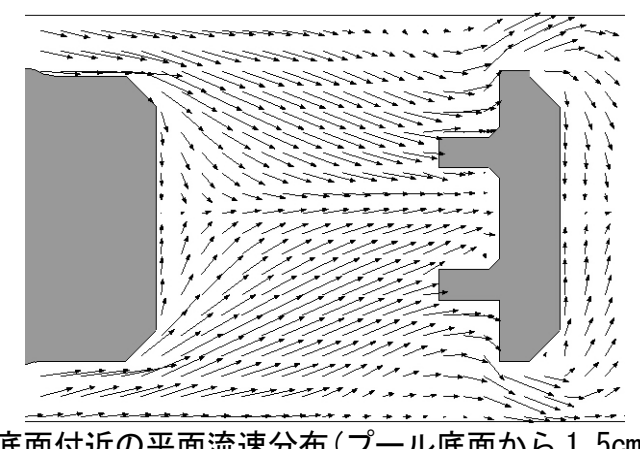

底面付近の平面流速分布 $($ プール底面から $1.5 \mathrm{~cm})$

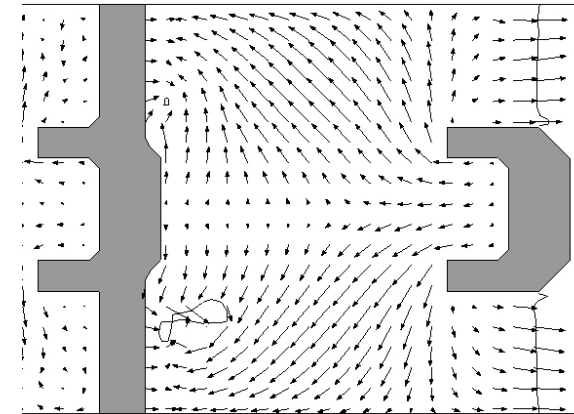

水面付近の平面流速分布（プール底面から $21.5 \mathrm{~cm}$ )

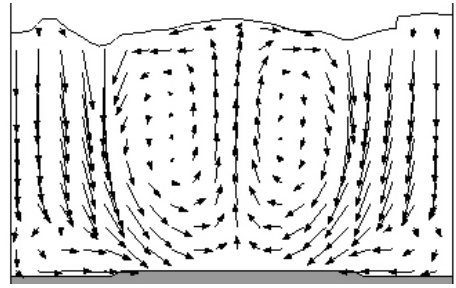

魚道直下流の横断流速分布（魚道下流面から $0.5 \mathrm{~cm}$ )

図-10５段目の魚道プール内の流況 (Case1-3)

ルを用い，移流項には一次風上差分を用いた．水路側面 がガラス，底面と魚道がアクリル板であることを考慮し てマニングの粗度係数 $n=0.01$ として，マニングスト リクラーの式を用いて, 相当粗度 $k_{s}=0.00018 \mathrm{~m}$ とした. 解析時間は，ケースにより異なるが，流況が安定するま での200秒から400秒とした. 以下で述べる解析結果は計 算終了時の瞬間值を示している.

\section{(2) 解析モデルの妥当性の検証}

図-4, 図-5 は，Case1 及び Case3 のプール中央の水面 形の実測值と解析值を比較したものである. Case1-1 の 流量が少ない場合には, 魚道中段付近で解析值の方が実 験值をやや下回るが，2 段目のプールから潜孔部のみの 


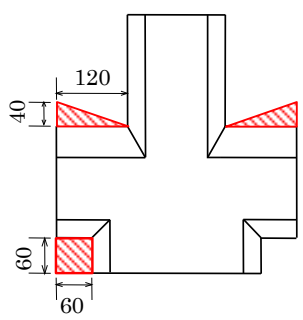

図-11 断面改良部（赤色斜線部を付加, 単位 $\mathrm{mm}$ )

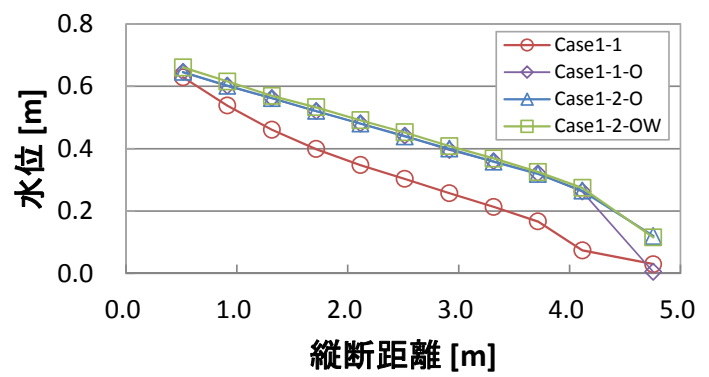

図-12 片側の潜孔を閉じた場合の水面形の変化

流れとなり, 流下寸るにつれてプール内の水位が低下寸 る様子が再現できている. Case1-3, Case3-1 及びCase3-1 では，解析值は実験結果を良好に再現できている．図-6 〜図-9 は，実験と解析結果の流況を各ケースについて 示したものであるが, これらの図からも解析による水面 の状況は実験結果を良く再現できていることがわかる.

次に，図-10 は，解析結果得られた 5 段目のプール内 の流速分布を示している. 縦断図及び底面付近の図よ り，切り欠き部を越流した流れはプランジングフローと なり，また，潜孔流はそのまま下流の潜孔部へ向かう流 れと下流側の魚道の非越流部である $\mathrm{U}$ 字部分に向かう 流れに分かれることがわかる. 水面付近の図 (水面付近 の乱れは落下水が空気を巻き込んだものである）からわ かるように, U 字箇所で流れが上昇し, 反時計回りの流 れが生じる. 魚道直下流の横断面流速より, 切り欠き部 では流れは下降し, 中央部で上昇流となる 2 次流を発生 することがわかる．これらの流速分布特性は，藤原ら ${ }^{5)}$ が現地観測との比較で解析的に示した，アイスハーバー 型魚道の流況をよく再現できていると考えられるため, 本研究で採用した解析モデルは実験結果の再現性を有 しているものと判断できる.

\section{3. 魚道の機能改善の検討}

\section{（1）魚道モデルの提案}

本研究では，Case1-1 で示したように，下流水位が低 下しても魚道機能が維持される構造を提案寸る．ただ し，下流水深が Case1-1 まで低下してしまうと最下流の 潜孔部も遡上できなくなる恐れがあるため, 本研究で は, 下流端水深が Case1-3 の半分程度まで低下(模型での 水深の低下量は $12 \mathrm{~cm}$ で，実物換算 $60 \mathrm{~cm}$ 程度の下流端

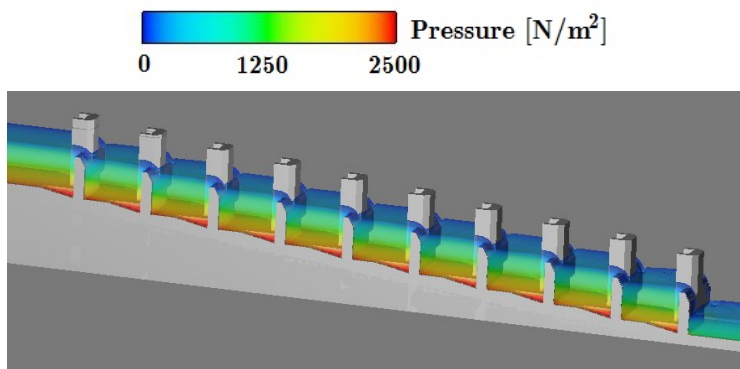

(a) Case1-2-0

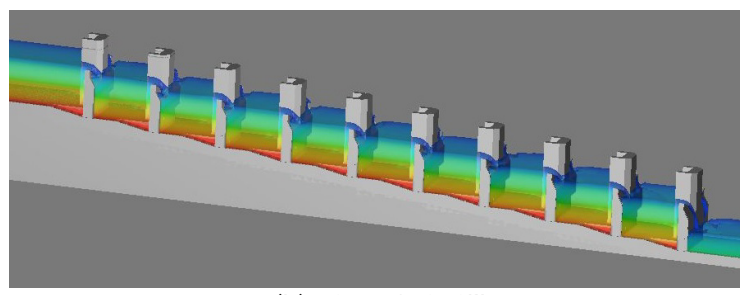

(b) Case1-2-OW

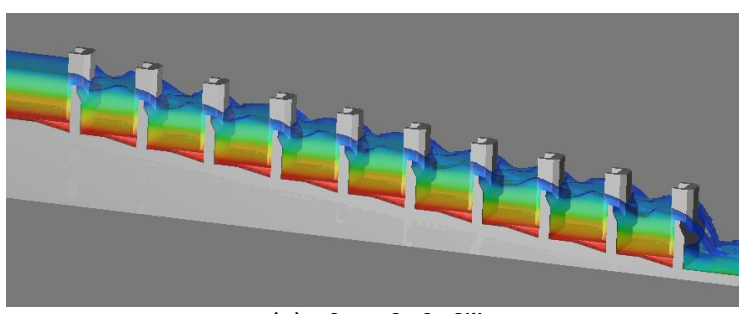

(c) Case3-2-OW

図-13 魚道機能改善ヶースの流況

における水位低下に相当)しても機能が維持されうるこ とを考えた。 このような水位条件下では，上流から 5 段 目の魚道から潜孔部のみの流れとなることが示されて いる7)。そこで，本研究では，両サイドにある潜孔部を 片側だけ閉じることを提案する。 その際，鬼束ら ${ }^{8}$ が遡 上率の向上のためには交互潜孔よりも片側潜孔の方が 適切であることを示していることを考慮して右岸側の 潜孔を全て閉じることとした，さらに，低流量時に越流 部の水深を確保寸るために, 水平の越流部の横断方向に 傾斜を持たせることで多様な越流水深を確保できるも のと考えて, 越流部に高さ $4 \mathrm{~cm}$ の三角柱の構造物を設 置した. 図-11 は, これらの魚道の改善状況を示してい る. 表-1 の改善欄には解析対象ケースを示している. ケース名の O は潜孔部(Orifice)を閉じた条件を示し，W は越流部(Weir)を改善したケースを示している.

\section{（2）潜孔部を閉じる効果の検討}

図-12 は, Case1-1 で小流量時に潜孔部のみの流れと なることを考慮して，この条件で潜孔の片側を閉じた Case1-1-O の水面形を示している. 図より，片側の潜孔 を閉じることで，下流端が自由流出であっても 10 段目 の魚道まで越流状態が確保できることがわかる. 改善モ デルケースとして下流端水位を $12 \mathrm{~cm}$ とした Case1-2-O と，越流部に傾斜を持たせた Case1-2-OW も同様にす心゙ てのプールで越流状態が維持される. 図-13 は各ケース 


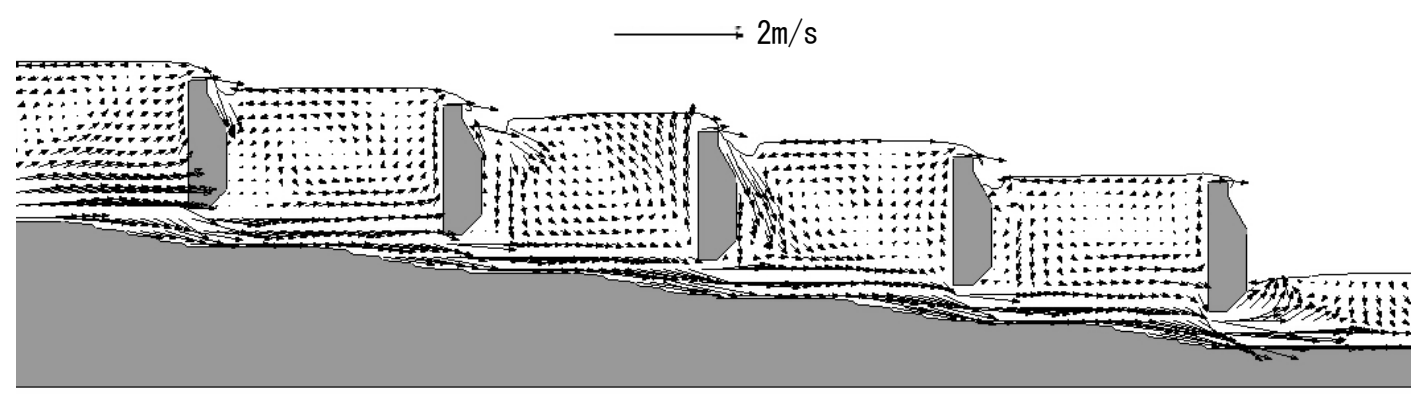

(a) Case1-2-0W

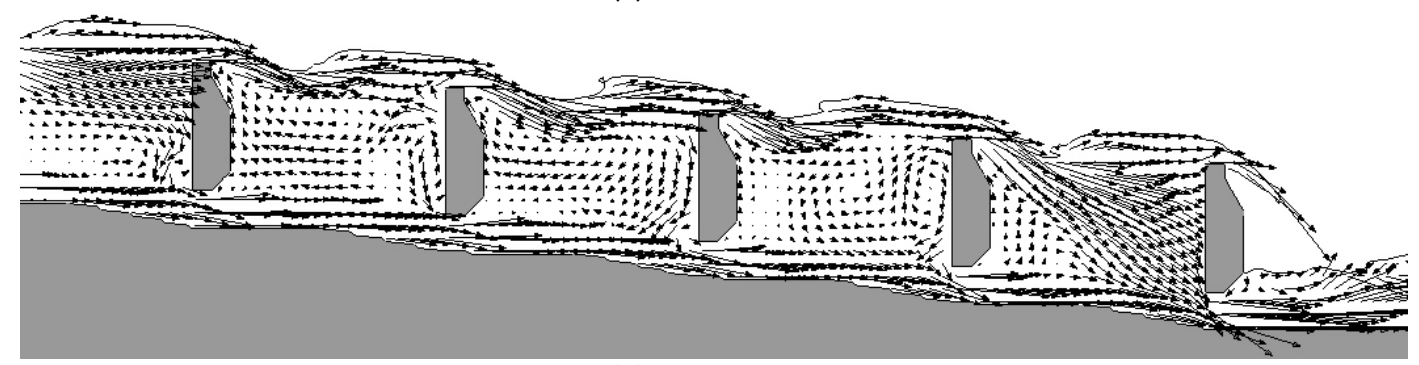

(b) Case3-2-OW

図-14 縱断面流速分布 (左岸から $5.5 \mathrm{~cm})$

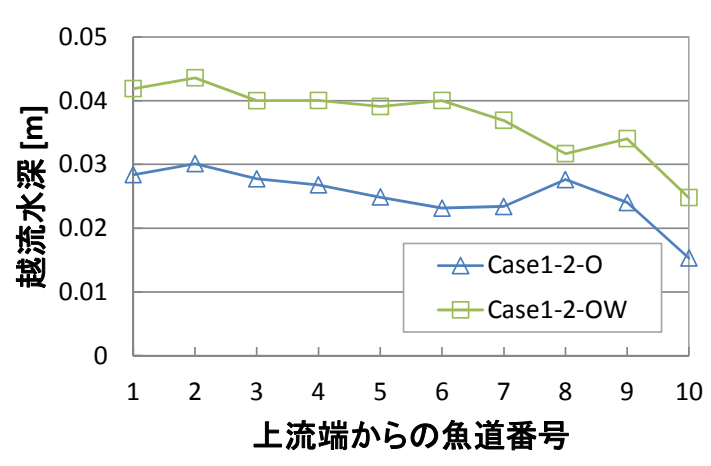

図-15 切欠部の越流水深の縱断分布 （左右岸の最大越流水深の平均値）

の流況を示しているが，この図からもすべてのプールで 水位が上昇し，越流状態となることがわかる．図-14 は 6 段目の魚道より下流側の左岸から $5.5 \mathrm{~cm}$ の断面流速分 布を示している. 流量が小さい Case1-2-OW の場合には 改善後もプランジングフローが維持されるが, 流量が大 きい Case3-2-OW の場合には, Case3-3 がプランジング フローであったのに対しストリーミングフローに変わ る. 鬼束ら ${ }^{9}$ はストリーミングフローの状況であっても 魚類の遡上を確認しており, 魚道機能は維持されると考 えられる。

\section{(3) 越流部の水深の検討}

図-15 は, Case1-2-O と, Case1-2-OW について, 切り 欠き部を越流寸る左右岸の最大水深の平均值の縦断分 布を示している. 10 段目の魚道については, 流量が少 なく下流端水位が低下した状況では魚類は潜孔部を利 用するため, 9 段目までの越流水深で検討する. 図より, Case1-2-O よりも, 越流部に三角柱を設置して傾斜を持 たせた Case1-2-OW の方が最大越流水深を約 $1 \mathrm{~cm}$ 程度大
きくすることができることがわかる. 解析モデルが, $1 / 5$ 縮尺を想定した魚道であることを考慮すると， Case1-2-O の場合もある程度の越流水深は確保できる が, 越流部に傾斜を持たせる方が越流水深が大きくなる ためより遡上しやすいと判断できる.

\section{（4）越流部，潜孔部の流速の検討}

図-16 は, Case1-2-O, Case1-2-OW, Case3-2-OW の 9 段 目と 10 段目の魚道の潜孔部入口から $2.5 \mathrm{~cm}$ 下流側の横 断面面における流速の大きさを示している. まず 9 段目 の魚道の越流部についてみると, 流量が小さい場合は越 流流速は $50 \mathrm{~cm} / \mathrm{s}$ 程度であり, 魚類は十分越流部を遡上 可能と判断できる. 流量が大きいCase3-2-OW では越流 流速が $1 \mathrm{~m} / \mathrm{s}$ 程度になる箇所もあるが, 流速が数十 $\mathrm{cm} / \mathrm{s}$ の箇所もあるため, 遡上可能と考えられる. 潜孔部につ いては， $1.3 \mathrm{~m} / \mathrm{s}$ 程度と流速が大きな箇所も見られるが, 潜孔部の上側で数十 $\mathrm{cm} / \mathrm{s}$ の箇所もあるため遡上可能と 判断できる.

次に 10 段目の魚道は, 水位低下時に魚類は潜孔部を 通過するため，ここでは潜孔部のみを検討する．10 段 目の潜孔部の流速は 9 段目の流速よりも大きくなる.ま た, 越流部に傾斜を持たせる Case1-2-OW と Case3-2-OW の方が潜孔部の流速が大きくなる. 潜孔部の上側に流速 が $1 \mathrm{~m} / \mathrm{s}$ 程度の箇所があるが, 断面流速は最大で $2 \mathrm{~m} / \mathrm{s}$ 程 度まで達する，魚類の突進速度について，泉ら ${ }^{10}$ は，淡 水魚の遊泳能力の定量的把握を目的として自然河川内 で円筒パイプを用いて突進速度に関する遊泳実験を行 い, 魚種・体長ごとの突進速度及びその持続時間につい て検討し, イワナ, ウグイ, オイカワ, ヤマメの魚が最 も速く通過した $50 \mathrm{~cm}$ 区間の遊泳速度を測定したとこ ろ，体長の 19 倍程度の值であることを明らかにした。 


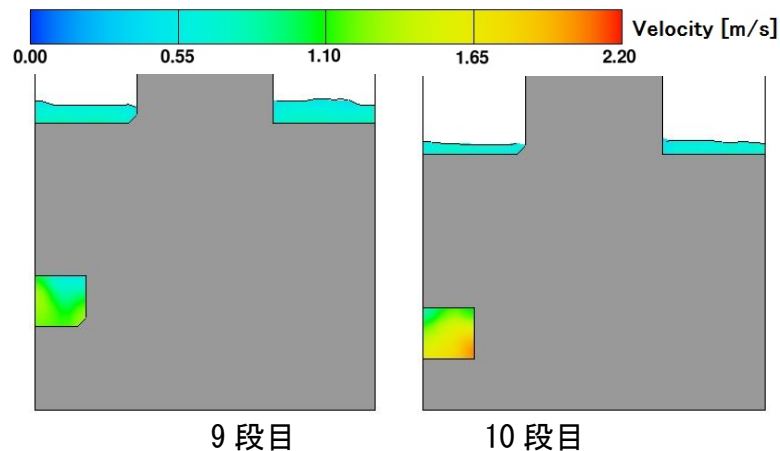

(a) Case1-2-0

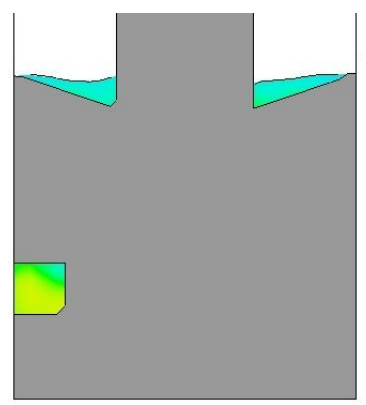

9 段目

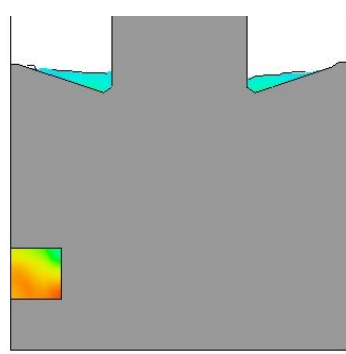

10 段目

(b) Case1-2-0W

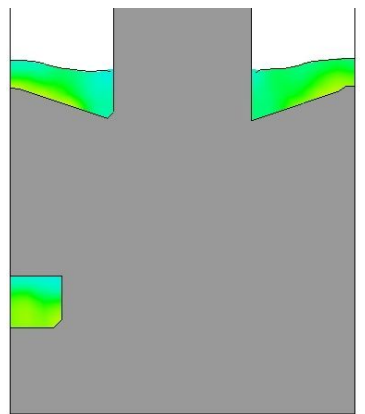

9 段目

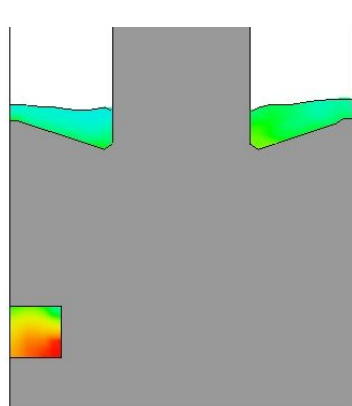

10 段目 (c) Case3-2-0W

図-16 潜孔出口横断面の流速分布

(潜孔入口から $2.5 \mathrm{~cm}$ の断面)

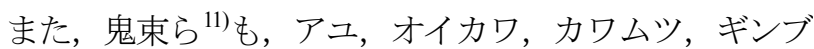
ナの突進速度を計測し，一般論として言われている体長 の 10 倍が成立せず， 4 種とも，20 倍程度で，最大で体 長の 30 倍程度以上といら結果を得ている。これらの実 験結果を参考にすると，体長が 5 6cm の幼魚であって も, $1 \mathrm{~m} / \mathrm{s}$ 程度以上の突進速度を有していると考えられる ため最下流端にある魚道の潜孔部の角であれば遡上可 能であると推察できる。したがって，最下流端の潜孔部 を遡上した魚類は，10 段目のプール内で休䕀できる上， 9 段目は越流部，潜孔部とも遡上可能であるため，提案 した魚道の機能は維持できると考えられる.

\section{4. 結論}

本研究では, 低流量, 河床低下時におけるアイスハー バ一型魚道の機能改善について 3 次元数值解析を用い
て検討した．以下に得られた主要な結論を示寸．

1) 越流部と潜孔部を有するアイスハーバー型魚道の流 況は，FLOW-3D による 3 次元解析により再現可能であ る.

2) 流量が少なく, 河床低下により下流端水深が半分程 度低下した場合においてもアイスハーバー型魚道の片 側の潜孔部を閉じることでプール水深が確保でき，魚類 が遡上可能となる.

3) 越流部に三角柱を設置して傾斜を持たせることで流 量が少ない場合においても越流水深を確保できる.

4) 下流端の水位が低下寸ると最下流端の潜孔部の流速 が大きくなるが，突進速度が体長の 20 倍程度とする研 究成果を参考にすると, 魚類は潜孔部を遡上可能である と考えられ，提案した魚道は低流量，水位低下時にも機 能を維持できると考えられる.

\section{参考文献}

1) 国土交通省:魚がのぼりやすい川づくりの手引き第 3 章, http://www.mlit.go.jp/river/shishin_guideline/kankyo/ kankyou/sakana_tebiki/pdf/shiryou3.pdf, p.69.

2）前野詩朗，尾上博則，宮内洋介：VOF 法による階段式 魚道の流れの数值解析, 土木学会水工学論文集, 第 45 巻, PP. 421-426, 2001

3) 前野詩朗, 小川 信: プールタイプ魚道の流れの数值 解析，土木学会水工学論文集，第 46 巻, pp.421-426, 2002.

4) 浪平篤，後藤眞宏 : 階段式魚道における汎用的な流況 予測のための数值解析手法, 応用力学論文集, Vol.9, pp.833-841, 2006.

5）藤原正幸，秋元麻衣，泉 完：VOF 法を用いたアイス ハーバー型魚道の三次元流況シミュレーション，農業 農村工学会全国大会講演要旨集,pp.160-161, 2007.

6) 後藤仁志，五十里洋行，酒井哲郎，望月貴文 : 3D-MPS 法による数值魚道の構築に関する基礎的検討, 水工学 論文集, 第 50 巻, pp.853-858, 2006.

7) Kumar, G. S., Nago, H., Maeno. S. and Hoshina K. : Hydraulics of Ice Harbor Type Fishway, Proc. of International Symposium on Fishways in Gifu, '95, pp. 79-86, 1995.

8）鬼束幸樹，秋山壽一郎，松田孝一郎，寺島大輔 : 潜孔 の設置位置がアユの遡上特性に及ぼす影響, 水工学論 文集, No.55, pp.1429-1434, 2011.

9) 鬼束幸樹, 秋山壽一郎, 森悠輔, 小林達也, 飯國洋平 : 階段式魚道におけるプール間落差と遡上率の関係，応 用力学論文集, Vol.11, pp.677-688, 2008.

10）泉完，工藤明，東信行，矢田谷健一，伊東竜太 : 自然 河川水を用いた淡水魚の突進速度に関する遊泳実験, 農業土木学会全国大会講演要旨集, pp.32-33, 2005.

11）鬼束幸樹, 秋山壽一郎, 山本晃義, 渡邊拓也，脇健樹 : 河川に生息する数魚種の突進速度に関する研究〜ア ユ，オイカワ，カワムツ，ギンブナを対象〜，土木学 会論文集 B, Vol.65, No.4, pp.296-307, 2009.

(2014. 9. 30 受付) 